\title{
Relationship of mineral elements in sheep grazing in the highland agro-ecosystem
}

\author{
Qingshan Fan', Zhaofeng Wang ${ }^{1}$, Shenghua Chang ${ }^{1}$, Zechen Peng ${ }^{1}$, Metha Wanapat $^{2}$, \\ Saman Bowatte ${ }^{1}$, and Fujiang Hou ${ }^{1, *}$
}

\begin{abstract}
* Corresponding Author: Fujiang Hou Tel: +86-931-8913047, Fax: +86-931-8910979, E-mail: cyhoufj@|zu.edu.cn
\end{abstract}

'State Key Laboratory of Grassland Agro-ecosystems; Key Laboratory of Grassland Livestock Industry Innovation, Ministry of Agriculture; College of

Pastoral Agriculture Science and Technology, Lanzhou University, Lanzhou 730020, China

${ }^{2}$ Tropical Feed Resources Research and Development Center (TROFREC), Department of Animal Science Faculty of Agriculture, Khon Kaen University, Khon Kaen 40002, Thailand

ORCID

Qingshan Fan

https://orcid.org/0000-0003-3724-516X

Zhaofeng Wang

https://orcid.org/0000-0002-8932-5906

Shenghua Chang

https://orcid.org/0000-0003-1561-7030

Zechen Peng

https://orcid.org/0000-0001-9702-1761

Metha Wanapat

https://orcid.org/0000-0002-7633-052X

Saman Bowatte

https://orcid.org/0000-0002-9610-9320

Fujiang Hou

https://orcid.org/0000-0002-5368-7147

Submitted Dec 17, 2018; Revised Feb 21, 2019; Accepted Apr 6, 2019
Objective: Minerals are one of the important nutrients for supporting the growth of sheep grazing in the highland, northwest of China. The experiment was conducted to investigate the relationship of both macro and micro minerals in sheep grazing in the highlands of six districts located in the Qilian Mountain of China.

Methods: Samples of herbage $(\mathrm{n}=240)$ and soil $(\mathrm{n}=240)$ were collected at random in a "W" shape across the area designated for harvesting from 24 farms, where the sheep commonly graze in October (winter) for mineral analyses. In addition, serum samples were taken via jugular vein from 20 sheep per farm from 24 farms ( $n=480$ samples in total) for serum minerals analyses. Mean values of macro and micro minerals were statistically compared among districts and the correlations among soil-plant-animal were statistically analyzed and correlations were regressed, as well.

Results: The results revealed that there were variations for both macro and micro minerals among districts. Statistical analysis of the correlation coefficients between herbage and sheep were significantly different for most of the minerals but not for $\mathrm{P}, \mathrm{Cu}$, and Se. Many correlation regression coefficients were found significantly different among minerals of herbage, soil, and sheep serum especially those of $\mathrm{K}, \mathrm{Na}, \mathrm{Fe}, \mathrm{Mn}$, and $\mathrm{Zn}$ (between herbage and sheep serum), and Fe and $\mathrm{Mn}$ (between herbage and soil), $\mathrm{Na}, \mathrm{Fe}, \mathrm{Mn}$, and $\mathrm{Zn}$ (between soil and sheep serum), respectively. The regression coefficient equations derived under this experiment for prediction of $\mathrm{Ca}\left(\mathrm{R}^{2}=0.618\right), \mathrm{K}\left(\mathrm{R}^{2}=0.803\right), \mathrm{Mg}\left(\mathrm{R}^{2}=0.767\right), \mathrm{Na}\left(\mathrm{R}^{2}=0.670\right), \mathrm{Fe}\left(\mathrm{R}^{2}=0.865\right)$, $\mathrm{Zn}\left(\mathrm{R}^{2}=0.950\right), \mathrm{Mn}\left(\mathrm{R}^{2}=0.936\right)$, and Se $\left(\mathrm{R}^{2}=0.630\right)$, resulted in significant $\mathrm{R}^{2}$ values.

Conclusion: It is inferred that the winter herbage minerals in all the districts were below the recommended levels for macro minerals which indicated there would be some mineral deficiencies in sheep grazing the herbage in these regions. Supplemental minerals may therefore play an important role in balancing the minerals available from the herbage in winter and would lead to increased productivity in sheep on the highland areas of China. These findings could be potentially applied to the other regions for improving the livestock productivity.

Keywords: Macro and Micro Mineral; Deficiency; Soil-plant-animal; Qilian Mountain Grassland; Correlations

\section{INTRODUCTION}

The Qilian Mountains, located on the northeastern margins of the Qinghai-Tibet Plateau, are composed of a string of mountains and valleys in the northwestern China. Several inland rivers including the Heihe, Shule, and Shiyang originate from the Qilian Mountains in Qinghai Province and provided valuable water resources for the neighboring lands [1]. Thus, the Qilian Mountains play a critical role in water conservation for regional sustainable development and serve as important ecological shelters in the northwest of China [2] and are also an important base of animal husbandry. Sheep grazing production is an essential component 
in the highlands of the northeastern part of Qilian Mountains where seasonal grazing is a predominant grazing system. The livestock graze on the natural pasture all year round, but pasture herbage cannot sufficiently provide the mineral requirements for grazing ruminants. Previous studies have reported that mineral deficiencies could have a great impact on livestock health and productivity [3,4]. Mineral deficiencies are a greater cause of losses than infectious diseases in many areas [5]. Mineral requirements of animals depend on many factors (age, stage of growth, lactation stage), and their balance with other nutrients [6]. The concentration of both macro and micro minerals in herbage can be highly variable as they are influenced by the agro-ecological factors, and the growth stage of herbage [7]. In turn, mineral availability in herbage can affect their status found in grazing animals, which may lead to mineral disorders (either excesses or deficiencies). The availability of minerals to sheep depends on many factors namely the production system or feeding practices [8]. Among many important factors, soil minerals play an important role in sheep productivity and health status because sheep obtain their required nutrients from the feeds and fodder trees, which in turn derive in nutrients from the soil. During the grazing process, livestock intentionally or unintentionally ingest a small amount of soil, so a small amount of mineral elements from soil is directly consumed by the animals (Figure 1) [9]. The contribution of soil type and its nutritive composition of herbage can greatly contribute to the performance of livestock and are dependable in each environment [10].

Assessment of minerals contained in soil and herbage where livestock graze is considered an important protocol [11]. The soil-plant-animal interrelationship has important consequences on nutritional imbalance and the productivity of livestock. The mineral profile of soil, plant, and animals has been reported by Sharma [12]; however, it has not been studied in detail in the northeastern highland of Qilian Mountains, China. Therefore, this experiment aimed to assess the status of essential minerals, both major and micro minerals, contained in soil herbage and sheep serum in areas where sheep are grazing in the highlands of Qilian Mountains to determine the mineral profile and predict mineral requirements.

\section{MATERIALS AND METHODS}

\section{Animal care}

The experimental procedures used in this study were approved by the Animal Ethics Committee of the Gansu Province and were performed in accordance with good scientific practices and national legislation.

\section{Study site and vegetation}

Six districts in the eastern part of the Qilian Mountains of the China were the study sites (Figure 2): Dahe township (38 $54^{\prime} 40.09^{\prime \prime}-38^{\circ} 54^{\prime} 46.94^{\prime \prime} \mathrm{N}, 99^{\circ} 31^{\prime} 58.61^{\prime \prime}-99^{\circ} 32^{\prime} 3.76^{\prime \prime} \mathrm{E}, 2,877$ to 3,013 m altitude); Qilian county $\left(38^{\circ} 11^{\prime} 26.23^{\prime \prime}-38^{\circ} 14^{\prime} 43.15^{\prime \prime} \mathrm{N}\right.$, $100^{\circ} 10^{\prime} 42.21^{\prime \prime}-100^{\circ} 13^{\prime} 21.32^{\prime \prime} \mathrm{E}, 2,984-3,009 \mathrm{~m}$ altitude); Gangcha county $\left(37^{\circ} 17^{\prime} 31.53^{\prime \prime}-37^{\circ} 24^{\prime} 38.25^{\prime \prime} \mathrm{N}, 100^{\circ} 27^{\prime} 3.53^{\prime \prime}-100^{\circ}\right.$ $46^{\prime} 13.39^{\prime \prime} \mathrm{E}, 3,024-3,048 \mathrm{~m}$ altitude); Huangcheng town (37 $53^{\prime} 19^{\prime \prime}-37^{\circ} 56^{\prime} 46.28^{\prime \prime} \mathrm{N}, 101^{\circ} 35^{\prime} 29^{\prime \prime}-101^{\circ} 49^{\prime} 47.32^{\prime \prime} \mathrm{E}, 2,498-2,880$ $\mathrm{m}$ altitude); Tianjun county $\left(37^{\circ} 40^{\prime} 13.39^{\prime \prime}-37^{\circ} 42^{\prime} 21.32^{\prime \prime} \mathrm{N}, 100^{\circ}\right.$ $24^{\prime} 15.28^{\prime \prime}-100^{\circ} 25^{\prime} 18.33^{\prime \prime} \mathrm{E}, 3,651-3,728 \mathrm{~m}$ altitude); Tianzhu county ( $36^{\circ} 57^{\prime} 49.44^{\prime \prime}-37^{\circ} 12^{\prime} 13.25^{\prime \prime} \mathrm{N}, 102^{\circ} 47^{\prime} 13.84^{\prime \prime}-102^{\circ} 59^{\prime}$ $54.26^{\prime \prime} \mathrm{E}, 3,200-3,540 \mathrm{~m}$ altitude). The study sites were typical of the pastoral livestock production system of the highland Qilian Mountains, having short summer (July-August) and annual temperature between -0.4 and $9.6^{\circ} \mathrm{C}$. In general, the vegetation in the sites consists of typical alpine meadows (Gangcha county and Tianzhu county) and grassland (Dahe township, Qilian county, Huangcheng town, and Tianjun county). Trial paddocks had been grazed at a high stocking rate prior to this study. A typical alpine meadow consists of Stipa capillata as dominant species, with the associated companion species being mainly Thermopsis lanceolate, Kobresia myosuroides, Gentiana macrophylla, Oxytropis ochrocephala, Leontopodium leontopodioides, Potentilla chinensis, Poa annua, Kobresia myosuroides, Koeleria cristata, Plantago asiatica, Silene aprica, and Stellera chamaejasme. A typical alpine grassland consists of Potentilla fruticose, Elymus dahuricus, and Stipa capillata as dominant species, with the associated companion species being mainly Potentilla anserine, Iris lacteal, Epilobium palustre, Trigonotis peduncularis, Koeleria cristata, Lancea tibetica, Oxytropis ochrocephala, Poa annua, Leontopodium

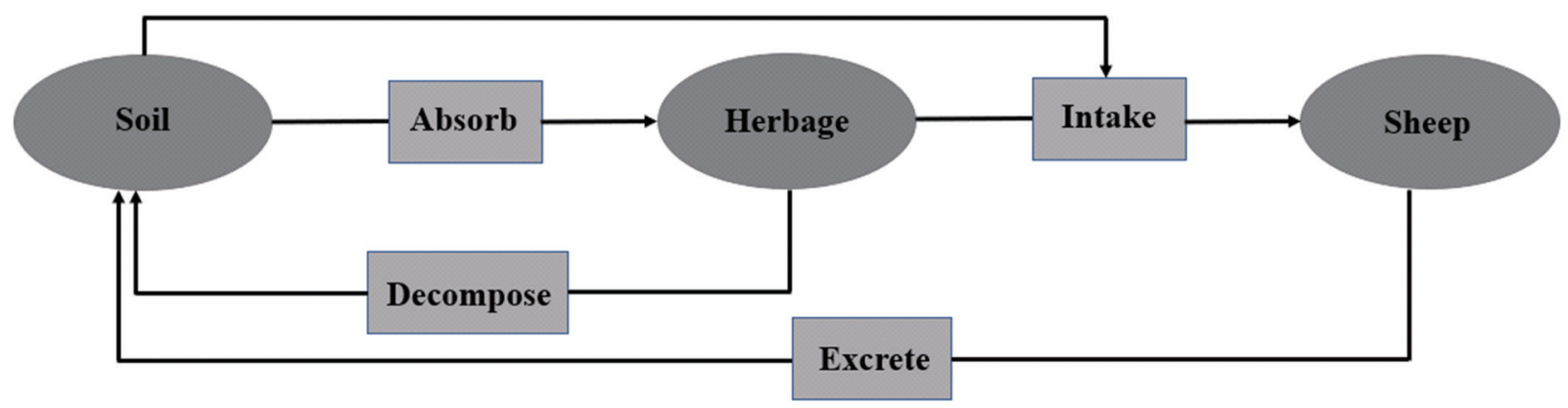

Figure 1. The cyclic route of mineral elements in grassland grazing system. 


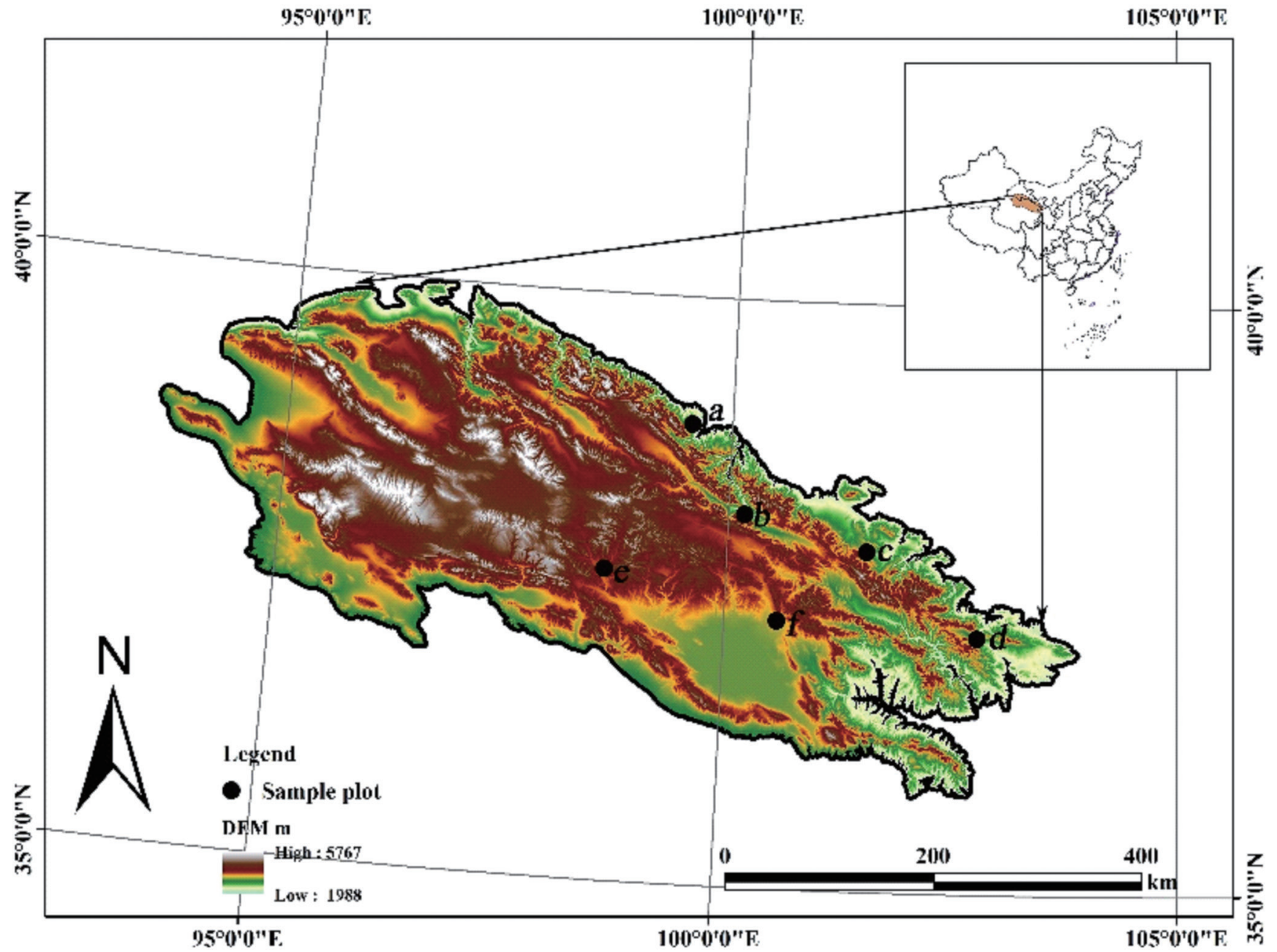

Figure 2. Details of the sampling sites. (a) Dahe township, (b) Qilian county, (c) Huangcheng town, (d) Tianzhu county, (e) Tianjun county, (f) Gangcha county.

leontopodioides, Lomatogonium rotatum, Silene aprica, Polygonum viviparum, Ptilagrostis concinna, Deyeuxia arundinacea, Silene aprica, Potentilla chinensis, Dendranthema morifolium, Gentiana scabra, Medicago falcata, Artemisia, Polygonaceae, and Hippophae rhamnoides.

The management of the sheep

The Gansu Alpine Merino and Tibetan sheep were used in this experiment, with age of 7 to 10 months, and each sheep farm maintained more than 280 sheep. Eighty sheep were randomly assigned under the experimental sites. Mean body weights of the sheep were $30.7 \pm 6.4 \mathrm{~kg}$. All sheep grazed on herbage and followed the local grazing management practices.

Sampling of herbage, soil and blood of sheep

Samples of soil, herbage, and blood serum were collected from randomly selected four smallholder sheep farms of each district during October. Soil samples were taken from the soil in the layer of 0 to $15 \mathrm{~cm}$ depth from 10 different areas of each sheep farm, in total of 240 soil samples (40 from each district) were collected from the four districts of the Qilian Mountain. After sun-drying, the soil samples were processed through a $0.25 \mathrm{~mm}$ sieve for the laboratory analysis. A total of 240 herbage samples were collected at random in a "W" shape across the area designated for harvesting from the pasture where the sheep grazed in each district. The herbage samples were collected by cutting off the top portion and storing it in polythene bags for later chemical analysis. Approximately $10 \mathrm{~mL}$ sample of blood was collected from the jugular vein of each sheep. A total of 480 blood samples were collected from sheep maintained at 24 smallholder sheep farms. Each sample of blood was then centrifuged at 2,000 $\mathrm{g}$ for $15 \mathrm{~min}$, and the supernatant serum was then collected into polyethylene tubes and stored at $-20^{\circ} \mathrm{C}$ until analysis.

\section{Mineral analysis}

Approximately $0.2 \mathrm{~g}$ from each of the dried soil samples was digested for $20 \mathrm{~min}$ at $140^{\circ} \mathrm{C}$ and $15 \mathrm{~atm}$ in $5 \mathrm{~mL}$ of concen- 
trated nitric acid ('suprapur' grade), $2 \mathrm{~mL}$ hydrochloric acid, $1 \mathrm{~mL}$ hydrofluoric acid and, $1 \mathrm{~mL}$ of $30 \% \mathrm{w} / \mathrm{v}$ hydrogen peroxide. The digested samples were cooled to room temperature, transferred to a teflon cup, $1 \mathrm{~mL}$ perchloric acid was added, and the hydrofluoric acid used for the analysis of total Se in the soil was removed $\left(180^{\circ} \mathrm{C}, 10 \mathrm{~min}\right)$.

Approximately $0.2 \mathrm{~g}$ of each of the dried herbage samples was digested for $5 \mathrm{~min}$ at $140^{\circ} \mathrm{C}$ and $15 \mathrm{~atm}$ in $5 \mathrm{~mL}$ of concentrated nitric acid ('suprapur' grade) and $1 \mathrm{~mL}$ of $30 \% \mathrm{w} / \mathrm{v}$ hydrogen peroxide. The $200 \mu \mathrm{L}$ of each serum sample was digested for $4 \mathrm{~min}$ at $140^{\circ} \mathrm{C}$, at $14 \mathrm{~atm}$ in $5 \mathrm{~mL}$ of concentrated nitric acid ('suprapur' grade) in a microwave digestion system (WX-4000, Shanghai Qiyao Ltd. Co., Shanghai, China). The digested samples were cooled to room temperature, transferred to volumetric flask, and diluted to $100 \mathrm{~mL}$ with 'ultrapure' water (Sartorius Arium 611 DI; Southeast Science and Technology Co., Ltd., Guangzhou, China). The solutions were filtered (Whatman No. 1 filter paper; Guangzhou Dian Ruihua Glass Experimental Instrument Co., Ltd., Guangzhou, China) before the estimation of different minerals.

Samples (soil, herbage, and serum) were analyzed for $\mathrm{Ca}$, $\mathrm{Mg}, \mathrm{K}, \mathrm{Na}, \mathrm{P}, \mathrm{Fe}, \mathrm{Zn}, \mathrm{Mn}$, and $\mathrm{Cu}$ using an ICP-AES analyzer (IRIS Advantage ER/S; Lanzhou University, Lanzhou, China) [13], and the analysis of Se was carried out by atomic fluorescence spectrophotometry [14].

\section{Statistical analysis}

The general linear model was used for analysis of variance of mineral concentrations in soil, herbage, and blood serum for different districts. Correlation coefficients of mineral content in soil, herbage, and sheep were determined from the data for mineral levels of soil, herbage, and blood serum, and the correlation between the assessed elements was estimated by Pearson's product-moment correlation coefficient. The regression equations on the relationship among soil-plant, plantanimal, and soil-plant-animal were determined using linear regression model. All the statistical analysis was carried out using SPSS statistical analysis software (SPSS for Windows,
Version 17.0, Chicago, IL, USA).

\section{RESULTS}

\section{Mineral profile of soil samples}

Based on the mineral analysis, there were differences between the mineral contents of soil samples collected from different districts. The mean ( \pm standard deviation) values of $\mathrm{Ca}, \mathrm{K}$, $\mathrm{P}, \mathrm{Mg}, \mathrm{Na}, \mathrm{Fe}, \mathrm{Mn}, \mathrm{Zn}, \mathrm{Cu}$, and Se in soils of different districts are given in Table 1. Among the macro minerals, the soil Ca content ranged from 280.9 to $552.9 \mathrm{mg} / \mathrm{kg}$ dry matter (DM), while P content was from 6.80 to $12.4 \mathrm{mg} / \mathrm{kg} \mathrm{DM}$. The soil minerals of the study area were classified below the recommended level for $\mathrm{P}$ and $\mathrm{Mg}$. $\mathrm{K}$ and Ca contents were significantly different among districts. Among other minerals, Fe contents were relatively high $(190.2 \pm 18.8 \mathrm{mg} / \mathrm{kg}$ DM against the recommended level of $2.5 \mathrm{mg} / \mathrm{kg} \mathrm{DM}$ ). Mn concentrations in soil samples in the investigated sites were significantly higher than the recommended level. Similarly, the $\mathrm{Cu}$ concentration was found to be higher than the recommended level in the majority of the soil samples. Evidently, all the soil samples contained higher concentrations of $\mathrm{Fe}$ and $\mathrm{Zn}$ than those of the recommended level.

\section{Mineral content in herbage}

The concentrations of both macro and micro minerals were variable among all the districts. The data are presented in Table 2. Fe and Mn contents in herbage of different districts were invariably higher than the recommended level. Similarly, the $\mathrm{Ca}, \mathrm{Mg}$, and Se concentrations were found to be higher than the recommended level in the majority of the herbage. Except for one district, the herbage samples obtained from other five districts were deficient in K. Most of the herbage samples were deficient in $\mathrm{P}$ and $\mathrm{Na}$. The extent of deficiency was very high in case of $\mathrm{Na}$. The recommended level of $\mathrm{Na}$ in herbage has been reported to range between 700 and 1,000 $\mathrm{mg} / \mathrm{kg} \mathrm{DM}$, but under the present study it was found that mean concentration of $\mathrm{Na}$ in herbage was only $77.14 \mathrm{mg} / \mathrm{kg}$ DM.

Table 1. Concentrations ( $\mathrm{mg} / \mathrm{kg}$ dry matter) of mineral elements in soil (mean $\pm \mathrm{SD}$ )

\begin{tabular}{|c|c|c|c|c|c|c|c|c|c|c|}
\hline District name & $\mathrm{Ca}$ & $\mathrm{K}$ & $\mathbf{P}$ & $\mathrm{Mg}$ & $\mathrm{Na}$ & $\mathrm{Fe}$ & Mn & $\mathrm{Zn}$ & $\mathrm{Cu}$ & $\mathrm{Se}^{1)}$ \\
\hline Dahe township & $465.78 \pm 16.54^{c}$ & $153.93 \pm 8.75^{d}$ & $8.60 \pm 0.27^{d}$ & $17.41 \pm 0.19^{c}$ & $13.92 \pm 0.33^{b}$ & $144.69 \pm 7.92^{e}$ & $6.88 \pm 0.48^{e}$ & $113.65 \pm 4.53^{d}$ & $0.29 \pm 0.01^{c}$ & $0.09 \pm 0.01^{d}$ \\
\hline Tianjun county & $393.35 \pm 15.31^{d}$ & $147.73 \pm 12.43^{e}$ & $12.49 \pm 1.18^{a}$ & $10.74 \pm 0.53^{f}$ & $15.35 \pm 0.49^{a}$ & $297.47 \pm 12.36^{a}$ & $18.62 \pm 1.21^{\mathrm{a}}$ & $116.75 \pm 9.46^{\mathrm{ab}}$ & $0.46 \pm 0.03^{a b}$ & $0.13 \pm 0.00^{b}$ \\
\hline Qilian county & $485.36 \pm 17.07^{b}$ & $142.73 \pm 12.43^{f}$ & $8.71 \pm 1.39^{d}$ & $15.68 \pm 0.35^{d}$ & $14.07 \pm 1.70^{b}$ & $153.85 \pm 9.80^{d}$ & $8.57 \pm 0.18^{d}$ & $115.82 \pm 4.45^{c}$ & $0.45 \pm 0.05^{a b}$ & $0.11 \pm 0.01^{c}$ \\
\hline Tianzhu county & $280.97 \pm 13.27^{\dagger}$ & $212.48 \pm 12.42^{\mathrm{a}}$ & $9.47 \pm 0.41^{c}$ & $18.03 \pm 1.37^{b}$ & $14.13 \pm 0.83^{b}$ & $208.21 \pm 14.47^{b}$ & $11.06 \pm 0.50^{b}$ & $116.14 \pm 3.82^{b c}$ & $0.48 \pm 0.02^{\mathrm{a}}$ & $0.08 \pm 0.01^{e}$ \\
\hline Gangcha county & $296.91 \pm 12.04^{e}$ & $159.64 \pm 13.81^{c}$ & $6.80 \pm 1.22^{e}$ & $14.91 \pm 0.38^{e}$ & $13.47 \pm 0.30^{b}$ & $154.91 \pm 11.42^{d}$ & $8.89 \pm 0.34^{d}$ & $115.72 \pm 6.19^{c}$ & $0.43 \pm 0.02^{b}$ & $0.10 \pm 0.01^{d}$ \\
\hline Huangcheng town & $552.96 \pm 22.38^{a}$ & $169.98 \pm 11.09^{b}$ & $11.56 \pm 2.38^{b}$ & $20.92 \pm 2.47^{\mathrm{a}}$ & $15.81 \pm 1.81^{\mathrm{a}}$ & $182.32 \pm 11.27^{c}$ & $10.33 \pm 0.50^{c}$ & $117.15 \pm 2.97^{\mathrm{a}}$ & $0.44 \pm 0.02^{b}$ & $0.18 \pm 0.01^{a}$ \\
\hline Significance of region & $<0.0001$ & $<0.0001$ & $<0.0001$ & $<0.0001$ & $<0.0001$ & $<.0001$ & $<0.0001$ & $<0.0001$ & $<0.0001$ & $<0.0001$ \\
\hline Overall (mean \pm SD) & $412.56 \pm 16.76$ & $164.42 \pm 13.93$ & $9.60 \pm 1.95$ & $16.28 \pm 3.19$ & $14.46 \pm 0.97$ & $190.24 \pm 18.84$ & $10.73 \pm 1.62$ & $115.87 \pm 3.89$ & $0.44 \pm 0.05$ & $0.11 \pm 0.03$ \\
\hline Recommended level ${ }^{2)}$ & 72 & 37 & 17 & 30 & - & 2.5 & 5 & 2.5 & 0.3 & 0.5 \\
\hline
\end{tabular}

SD, standard deviation.

1) Total concentration for $S e$ in soils.

2) Recommended levels for Ca, Mn, Zn, and Cu from Rhue [15]; Recommended levels for P, Mg, K, Fe, Co, and Se from Viets [16].

a-f Means with different superscripts between districts differ significantly $(p<0.01)$. 
Table 2. Macro and micro mineral concentrations (DM) in herbage samples (mean \pm SD)

\begin{tabular}{|c|c|c|c|c|c|c|c|c|c|c|}
\hline \multirow{2}{*}{ District name } & $\mathrm{Ca}$ & $\mathrm{K}$ & $\mathbf{P}$ & $\mathrm{Mg}$ & $\mathrm{Na}$ & $\mathrm{Fe}$ & $\mathrm{Mn}$ & $\mathrm{Zn}$ & $\mathrm{Cu}$ & Se \\
\hline & \multicolumn{4}{|c|}{ 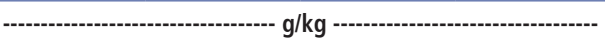 } & \multicolumn{6}{|c|}{ ו- } \\
\hline Dahe twnship & $8.83 \pm 0.23^{b}$ & $2.85 \pm 0.19^{c}$ & $0.76 \pm 0.02^{c}$ & $1.26 \pm 0.03^{\mathrm{e}}$ & $51.51 \pm 3.08^{\text {cd }}$ & $227.04 \pm 12.98^{\mathrm{e}}$ & $62.31 \pm 3.70^{f}$ & $19.20 \pm 1.48^{d}$ & $13.20 \pm 2.32^{c}$ & $0.04 \pm 0.00^{c}$ \\
\hline Tianjun & $32 \pm 0.09^{\mathrm{a}}$ & $3.58 \pm 0.08^{b}$ & $0.96 \pm 0.01^{\mathrm{a}}$ & $1.72 \pm 0.02^{\mathrm{a}}$ & $68.17 \pm 2.64^{b}$ & $334.73 \pm 14.27^{\mathrm{a}}$ & $93.92 \pm 2.69^{\mathrm{a}}$ & $32.25 \pm 0.73^{\mathrm{a}}$ & $15.88 \pm 2.67^{\mathrm{a}}$ & $0.07 \pm 0.00^{\mathrm{a}}$ \\
\hline Qilian C & $70 \pm 0.13^{b}$ & $2.67 \pm 0.17^{c}$ & $0.78 \pm 0.03^{c}$ & $1.65 \pm 0.02^{b}$ & $55.33 \pm 2.42^{c}$ & $237.21 \pm 13.27^{d}$ & $65.46 \pm 0.81^{e}$ & $21.19 \pm 0.85^{c}$ & $15.26 \pm 0.79^{a b}$ & $0.03 \pm 0.00^{d}$ \\
\hline Tianzhu col & $92 \pm 0$ & $3.48 \pm 0.10^{b}$ & $0.66 \pm 0.03^{d}$ & $1.56 \pm 0.03^{d}$ & $69.01 \pm 9.90^{b}$ & $285.57 \pm 11.40^{\mathrm{b}}$ & $77.78 \pm 4.83^{b}$ & $26.82 \pm 0.69^{b}$ & $13.29 \pm 1.70^{c}$ & $0.05 \pm 0.00^{b}$ \\
\hline Gangcha & $9 \pm 0$ & $5.60 \pm 0.29^{a}$ & $0.68 \pm 0.02^{d}$ & $1.18 \pm 0.02^{f}$ & $45.17 \pm 2.86^{d}$ & $264.86 \pm 12.18^{c}$ & $73.42 \pm 1.23^{d}$ & $21.47 \pm 1.62^{c}$ & $13.41 \pm 1$ & $0.05 \pm 0.01^{b}$ \\
\hline Huangcheng town & $8.77 \pm 0.20^{b}$ & $2.70 \pm 0.20^{c}$ & $0.85 \pm 0.02^{b}$ & $1.60 \pm 0.04^{c}$ & $173.67 \pm 8.82^{\mathrm{a}}$ & $265.59 \pm 11.78^{c}$ & $75.58 \pm 2.58^{c}$ & $21.61 \pm 1.55^{c}$ & $14.55 \pm 0.47^{b}$ & $0.07 \pm 0.00^{\circ}$ \\
\hline Significance of region & $<0.0001$ & $<0.0001$ & $<0.0001$ & $<0.0001$ & $<0.0001$ & $<0.0001$ & $<0.0001$ & $<0.0001$ & $<0.0001$ & $<0.0001$ \\
\hline Overall (mean \pm SD) & $8.34 \pm 1.27$ & $3.48 \pm 0.17$ & $0.78 \pm 0.11$ & $1.49 \pm 0.21$ & $77.14 \pm 7.49$ & $269.17 \pm 15.95$ & $74.75 \pm 8.34$ & $23.76 \pm 4.55$ & $14.26 \pm 1.19$ & $0.05 \pm 0.01$ \\
\hline Recommended level" & $1.4-7.0$ & 5.0 & 0.9-3.0 & 0.9-1.2 & $700-1000$ & 40 & 20-25 & $9-20$ & 4-14 & 0.05 \\
\hline
\end{tabular}

DM, dry matter; SD, standard deviation.

1) Recommended level according to nutrient requirements of sheep [17]. When a range is given, the higher values are for rapidly growing, pregnant, or lactating sheep and the lower values are for those at maintenance or with a low level of production.

${ }^{a-f}$ Means with different superscripts between districts differ significantly $(p<0.01)$.

\section{Mineral contents analysis in blood serum of sheep}

All mineral contents in serum of sheep are reported in Table 3. Results of blood serum of sheep analysis revealed variations in mineral contents among different districts. There were significant $(\mathrm{p}<0.05)$ differences in $\mathrm{Ca}, \mathrm{K}, \mathrm{P}, \mathrm{Mg}, \mathrm{Na}, \mathrm{Fe}$, $\mathrm{Mn}, \mathrm{Zn}$, and $\mathrm{Cu}$ concentrations in blood serum of sheep among the districts except for Se. $\mathrm{Ca}, \mathrm{K}, \mathrm{Mg}, \mathrm{Fe}, \mathrm{Mn}$, and $\mathrm{Zn}$ concentrations in serum samples were above the maximum level of marginal range, but all the serum $\mathrm{Na}$ concentrations were below the marginal range (Table 3 ) in all the districts.
Soil-plant-sheep interrelationship analysis

Significant correlation values were obtained between soil and herbage for $\mathrm{Ca}, \mathrm{P}, \mathrm{Na}, \mathrm{Fe}, \mathrm{Mn}$, and $\mathrm{Zn}$. The correlation values between herbage and sheep were significantly different for all the minerals studied except for $\mathrm{P}, \mathrm{Cu}$, and Se. Minerals (Na, $\mathrm{Fe}, \mathrm{Mn}$, and $\mathrm{Zn}$ ) (Table 4) between soil and sheep serum were found significantly different for correlation coefficients. The correlation values between herbage and sheep were highly significant ( $\mathrm{p}<0.01)$ for $\mathrm{K}(0.878), \mathrm{Na}(0.749), \mathrm{Fe}(0.825), \mathrm{Mn}$ (0.951), and $\mathrm{Zn}(0.916)$, and between soil and herbage for $\mathrm{Fe}$

Table 3. Macro and micro mineral concentrations ( $\mathrm{mg} / \mathrm{L})$ in blood serum of sheep (mean $\pm \mathrm{SD})$

\begin{tabular}{|c|c|c|c|c|c|c|c|c|c|c|}
\hline District name & $\mathrm{Ca}$ & K & $\mathbf{P}$ & $\mathrm{Mg}$ & $\mathrm{Na}$ & $\mathrm{Fe}$ & $\mathrm{Mn}$ & $\mathrm{Zn}$ & $\mathrm{Cu}$ & Se \\
\hline Dahe township & $109.61 \pm 2.47^{d}$ & $183.33 \pm 12.07^{e}$ & $40.12 \pm 1.48^{d}$ & $21.08 \pm 1.30^{d}$ & $2961.00 \pm 87.24^{d}$ & $6.62 \pm 1.31^{c}$ & $0.13 \pm 0.00^{c}$ & $1.21 \pm 0.05^{b}$ & $0.17 \pm 0.02^{c}$ & $0.02 \pm 0.00$ \\
\hline Tianjun county & $112.46 \pm 1.72^{c}$ & $202.01 \pm 12.62^{d}$ & $49.02 \pm 1.04^{a}$ & $24.45 \pm 1.21^{b}$ & $3,165.00 \pm 121.42^{b}$ & $7.73 \pm 0.43^{\mathrm{a}}$ & $0.15 \pm 0.02^{\mathrm{a}}$ & $1.39 \pm 0.06^{\mathrm{a}}$ & $0.45 \pm 0.04^{\mathrm{a}}$ & $0.03 \pm 0.01$ \\
\hline Qilian county & $119.39 \pm 2.27^{b}$ & $171.57 \pm 12.70^{f}$ & $43.22 \pm 1.25^{c}$ & $23.07 \pm 3.94^{c}$ & $3,052.17 \pm 154.81^{c}$ & $6.81 \pm 0.38^{b c}$ & $0.13 \pm 0.01^{b c}$ & $1.28 \pm 0.04^{b}$ & $0.19 \pm 0.01^{c}$ & $0.02 \pm 0.00$ \\
\hline Tianzhu county & $111.92 \pm 2.18^{c d}$ & $251.28 \pm 11.89^{\mathrm{a}}$ & $49.26 \pm 2.18^{a}$ & $24.15 \pm 3.27^{b c}$ & $3,145.83 \pm 64.84^{b}$ & $7.29 \pm 0.27^{\mathrm{ab}}$ & $0.14 \pm 0.01^{b}$ & $1.38 \pm 0.07^{\mathrm{a}}$ & $0.29 \pm 0.03^{b}$ & $0.02 \pm 0.00$ \\
\hline Gangcha county & $98.47 \pm 2.01^{e}$ & $213.81 \pm 11.99^{c}$ & $45.39 \pm 0.62^{b}$ & $18.63 \pm 2.91^{e}$ & $2,867.33 \pm 87.39^{e}$ & $6.97 \pm 0.41^{\mathrm{bc}}$ & $0.13 \pm 0.01^{c}$ & $1.28 \pm 0.06^{b}$ & $0.23 \pm 0.04^{c}$ & $0.03 \pm 0.00$ \\
\hline Huangcheng town & $123.24 \pm 2.16^{\mathrm{a}}$ & $231.77 \pm 11.92^{b}$ & $43.59 \pm 1.50^{c}$ & $28.12 \pm 2.31^{a}$ & $3,273.50 \pm 83.06^{\mathrm{a}}$ & $7.14 \pm 0.41^{b}$ & $0.13 \pm 0.00^{c}$ & $1.23 \pm 0.07^{b}$ & $0.31 \pm 0.02^{b}$ & $0.03 \pm 0.00$ \\
\hline Significance of region & $<0.0001$ & $<0.0001$ & $<0.0001$ & $<0.0001$ & $<0.0001$ & $<0.0001$ & $<0.0001$ & $<0.0001$ & $<0.0001$ & $>0.2781$ \\
\hline Overall (mean \pm SD) & $112.52 \pm 8.19$ & $208.96 \pm 17.65$ & $45.10 \pm 3.55$ & $23.25 \pm 4.15$ & $3,077.47 \pm 140.62$ & $7.09 \pm 0.51$ & $0.13 \pm 0.01$ & $1.29 \pm 0.09$ & $0.27 \pm 0.07$ & $0.03 \pm 0.01$ \\
\hline Recommended level ${ }^{1)}$ & $70-80$ & 93.6-156 & $31-46.5$ & 14.6-18.2 & $3,320-3,335$ & $0.19-2.21$ & 0.002 & $0.4-0.6$ & $0.19-0.58$ & $0.02-0.04$ \\
\hline
\end{tabular}

SD, standard deviation.

1) Recommended levels for $\mathrm{Ca}, \mathrm{K}, \mathrm{P}, \mathrm{Mg}, \mathrm{Na}, \mathrm{Fe}, \mathrm{Mn}, \mathrm{Zn}, \mathrm{Cu}, \mathrm{Co}$, and Se from Underwood [4].

a-f Means with different superscripts between districts differ significantly $(p<0.01)$.

Table 4. Soil-plant-animal relationship (correlation) in respect to macro and micro mineral status

\begin{tabular}{|c|c|c|c|c|c|c|c|c|c|c|}
\hline Mineral & $\mathrm{Ca}$ & $\mathrm{K}$ & $\mathbf{P}$ & $\mathrm{Mg}$ & $\mathrm{Na}$ & $\mathrm{Fe}$ & $\mathrm{Mn}$ & $\mathrm{Zn}$ & $\mathrm{Cu}$ & Se \\
\hline \multicolumn{11}{|l|}{ Soil-plant } \\
\hline Pearson correlation value & $0.592^{*}$ & 0.059 & $0.762^{*}$ & -0.143 & $0.683^{*}$ & $0.959 * *$ & $0.967 * *$ & $0.805^{*}$ & 0.124 & -0.528 \\
\hline p-value & 0.044 & 0.730 & 0.040 & 0.407 & 0.042 & 0.008 & 0.007 & 0.023 & 0.624 & 0.324 \\
\hline \multicolumn{11}{|l|}{ Plant-sheep } \\
\hline Pearson correlation value & $0.741^{*}$ & $0.878 * *$ & -0.228 & $0.672^{*}$ & $0.749 * *$ & $0.825^{* *}$ & $0.951 * *$ & 0.916 ** & 0.124 & 0.786 \\
\hline p-value & 0.017 & 0.007 & 0.264 & 0.026 & 0.008 & 0.004 & 0.001 & 0.002 & 0.624 & 0.079 \\
\hline \multicolumn{11}{|l|}{ Soil-sheep } \\
\hline Pearson correlation value & 0.227 & 0.232 & -0.140 & 0.731 & $0.752^{* *}$ & $0.913^{* *}$ & $0.965^{* *}$ & $0.935^{* *}$ & 0.433 & -0.319 \\
\hline p-value & 0.182 & 0.173 & 0.495 & 0.058 & 0.008 & 0.006 & 0.002 & 0.004 & 0.073 & 0.497 \\
\hline
\end{tabular}

* Significant at 0.05 level, ${ }^{* *}$ significant at 0.01 level. 
(0.959) and Mn (0.967). Nevertheless, such correlation coefficients were not found significantly different between those in sheep and soil except for $\mathrm{Na}(0.752), \mathrm{Fe}(0.913), \mathrm{Mn}(0.965)$, and $\mathrm{Zn}(0.935)$.

An assessment was conducted to assess the mineral contents in soil, herbage and sheep serum as independent values. Prediction equations that could predict the mineral contents in sheep requirements based on the mineral contents in soil and herbage are given in Table 5. Equations developed in the present study for prediction of $\mathrm{Ca}\left(\mathrm{R}^{2}=0.618\right), \mathrm{K}\left(\mathrm{R}^{2}=0.803\right)$, $\mathrm{Mg}\left(\mathrm{R}^{2}=0.767\right), \mathrm{Na}\left(\mathrm{R}^{2}=0.670\right), \mathrm{Fe}\left(\mathrm{R}^{2}=0.865\right), \mathrm{Mn}\left(\mathrm{R}^{2}=\right.$ $0.936), \mathrm{Zn}\left(\mathrm{R}^{2}=0.950\right)$, and Se $\left(R^{2}=0.630\right)$ and were found highly significant.

\section{DISCUSSION}

Most plants contain relatively low concentrations of $\mathrm{Na}$, as compared with the requirements of animals as reported by Mcdowell [3]. But the present investigation indicated that the concentrations of $\mathrm{Na}$ of Qilian Mountain herbage were extremely low (Table 2) and can only meet about $8 \%$ of the sheep's requirements (700 to $1,000 \mathrm{mg} / \mathrm{kg} \mathrm{DM}$ ) as reported by Freer [17]. However, the data obtained from sheep's serum samples showed that the extent of deficiency of $\mathrm{Na}$ was not too serious, even though they were below the minimal level, as recommended by Underwood [4] (Table 3). Xin [18] concluded that the relatively sufficient $\mathrm{Na}$ in sheep serum could be due to soil digestion as licking soil behavior of sheep was evident. This would partly explain that although there was a low level of $\mathrm{Na}$ from pasture there was a relatively higher serum $\mathrm{Na}$ of sheep. Deficiency of $\mathrm{Na}$ in herbage is commonly found in the northern part of China where salt-block supplements are offered to grazing sheep to achieve improved productivity [19]. Based on the results obtained under this study, the salt-block supplement is recommended.

During early growth stage herbage usually contains a high content of $\mathrm{P}$ but then declines rapidly as the herbage matures
[4]. Similar trend was found in the Qilian Mountain herbage, where $\mathrm{P}$ concentrations were below sheep requirements in most of the study areas (Table 2), which were in accordance with the findings of Masters [19]. All the serum P concentrations were within the marginal range of 31 to $46.5 \mathrm{mg} / \mathrm{L}$ [4] except in Tianjun county and Tianzhu county. This result suggested that the risk of $\mathrm{P}$ deficiency appears to be widespread in sheep during winter (Table 3). Those were consistent with findings reported by Long [20], in which the risk of $\mathrm{P}$ deficiency appears to be widespread in grazing yaks in late winter.

Previous studies showed that $\mathrm{K}$ concentrations in herbages would be reduced, as the herbage grows [21]. Our results showed that $\mathrm{K}$ concentrations in the winter herbages were lower than the recommended level of $5.0 \mathrm{~g} / \mathrm{kg} \mathrm{DM} \mathrm{[17]} \mathrm{in}$ most of the study areas. This result was in agreement with earlier reports Masters [19]. In the present study, although concentrations of $\mathrm{K}$ in soils were found to be higher than the recommended level, concentrations of the mineral in herbages obtained were lower than the recommended level. This result was similar to that given by Ashraf [22]. However, serum $\mathrm{K}$ concentrations were found at all above the marginal level of 93.6 to $156 \mathrm{mg} / \mathrm{L}$ [4] in all study areas. The high sheep serum of $K$ concentration could be attributed from soil licking of sheep when grazing during the winter season.

Although, the Mg concentrations in soils were below the requirement, the concentrations of herbage minerals were relatively higher than the recommended level (Table 2). This finding is similar to that illustrated by Kumaresan [8]. Accordingly, all the serum $\mathrm{Mg}$ concentrations (18.6 to $28.1 \mathrm{mg} / \mathrm{L}$ ) in grazing sheep were all above the limiting range of 14.6 to 18.2 $\mathrm{mg} / \mathrm{L}$ [4]. Thus, the sheep has a sufficient Mg status during winter. The results agreed with the former reports that $\mathrm{Mg}$ deficiency in sheep seldomly occurred in the northwest of China [19].

$\mathrm{Ca}$ is vital to reduce the acidity of soil and is also used as a major nutrient for normal herbage growth [15]. In this study,

Table 5. Regression equation on soil-plant-animal continuum in relation to mineral status

\begin{tabular}{|c|c|c|c|c|c|c|c|c|}
\hline Mineral & $\begin{array}{l}\text { Regression equation to } \\
\text { predict mineral content } \\
\text { in pasture based on the } \\
\text { mineral status of soil }\end{array}$ & $\mathrm{R}^{2}$ & $\begin{array}{l}\text { Regression equation to predict } \\
\text { mineral content in sheep based } \\
\text { on the mineral status of pasture }\end{array}$ & $\mathbf{R}^{2}$ & $\begin{array}{l}\text { Regression equation to } \\
\text { predict mineral content in } \\
\text { sheep based on the mineral } \\
\text { status of soil }\end{array}$ & $\mathrm{R}^{2}$ & $\begin{array}{l}\text { Regression equation to predict } \\
\text { mineral content in sheep based } \\
\text { on the mineral status of soil and } \\
\text { plant }\end{array}$ & $\mathrm{R}^{2}$ \\
\hline $\mathrm{Ca}$ & $A=0.008 B+5.241$ & 0.650 & $C=1.460 A+100.342$ & 0.549 & $C=0.060 B+87.621$ & 0.052 & $C=0.076 B-2.087 A+98.559$ & 0.618 \\
\hline K & $A=0.003 B+3.046$ & 0.004 & $C=6.115 A+187.672$ & 0.771 & $C=1.030 B+39.589$ & 0.054 & $C=1.018 B+4.756 A+25.101$ & 0.803 \\
\hline$P$ & $A=0.033 B+0.464$ & 0.581 & $C=-6.817 A+49.508$ & 0.052 & $C=-0.479 B+48.620$ & 0.020 & $C=-0.948 B+22.597 A+37.577$ & 0.263 \\
\hline $\mathrm{Mg}$ & $A=-0.009 B+1.648$ & 0.020 & $C=11.109 A+6.616$ & 0.731 & $C=0.367 B+17.267$ & 0.138 & $C=0.480 B+12.163 \mathrm{~A}-2.778$ & 0.767 \\
\hline $\mathrm{Na}$ & $A=31.575 B-379.525$ & 0.563 & $C=2.352 A+2,896.054$ & 0.562 & $C=108.414 B+1,509.506$ & 0.752 & $C=63.969 B+1.408 A+2,043.723$ & 0.670 \\
\hline $\mathrm{Fe}$ & $A=0.655 B+144.384$ & 0.920 & $C=0.011 A+3.903$ & 0.681 & $C=0.007 B+5.600$ & 0.833 & $C=-0.005 B+0.019 A+2.906$ & 0.865 \\
\hline $\mathrm{Mn}$ & $A=2.594 B+47.068$ & 0.934 & $C=0.001 A+0.079$ & 0.904 & $C=0.002 B+0.111$ & 0.931 & $C=0.001 B+0.001 A+0.087$ & 0.936 \\
\hline $\mathrm{Zn}$ & $A=3.925 B-430.092$ & 0.648 & $C=0.015 A+0.887$ & 0.838 & $C=0.073 B-7.219$ & 0.874 & $C=0.037 B+0.009 A-3.251$ & 0.950 \\
\hline $\mathrm{Cu}$ & $A=3.162 B+12.693$ & 0.015 & $C=0.035 A-0.229$ & 0.158 & $C=0.824 B-0.085$ & 0.187 & $C=0.724 B+0.032 A-0.485$ & 0.308 \\
\hline Se & $A=-0.675 B+0.124$ & 0.278 & $C=-0.099 A+0.028$ & 0.418 & $C=0.312 B-0.012$ & 0.102 & $C=0.340 B+0.041 A-0.018$ & 0.630 \\
\hline
\end{tabular}

A mineral content in herbage; B mineral content in soil; C mineral content in sheep. 
Ca concentration in the soil was about four times higher when compared with the recommended level of $72 \mathrm{mg} / \mathrm{kg} \mathrm{DM}$ in all testing sites. High levels of Ca contained in soil may increase Ca concentrations in herbage [23]. This is consistent with the current research results. Likewise, Mcdowell [3] reported that $\mathrm{Ca}$ is not likely limited in herbage diets. Our results showed that all the concentrations of herbage Ca were all within the recommended range of 1.4 to $7.0 \mathrm{mg} / \mathrm{kg} \mathrm{DM}$ [17], furthermore, Ca in serum of sheep also was sufficient (Table 3). These results were similar to those reported earlier by Masters [19].

The possible reasons for micro mineral deficiencies across China are variable with the environment and soil structure. Sheep production is largely grass and herbage based. If the soil cannot supply sufficient trace minerals to the plants that animals are consuming, a deficiency will occur. Soil testing may indicate gross deficiencies but should only be used as a guide when considering the trace element status of livestock. The average concentrations of trace elements values of soils in China were as following [16]: Fe (2.5 mg/kg DM), Mn (5 $\mathrm{mg} / \mathrm{kg} \mathrm{DM}), \mathrm{Zn}(2.5 \mathrm{mg} / \mathrm{kg} \mathrm{DM}), \mathrm{Cu}(0.3 \mathrm{mg} / \mathrm{kg} \mathrm{DM})$, and $\mathrm{Se}(0.5 \mathrm{mg} / \mathrm{kg} \mathrm{DM})$. Results of the present study revealed that the surface soils were much higher when compared with the average value of soils except for Se.

Herbage varies widely in micro mineral content due to soil type, $\mathrm{pH}$, vegetation type, and horizontal distribution [24,25]. In the present experiment, it was observed that the $\mathrm{Cu}, \mathrm{Mn}$, $\mathrm{Fe}, \mathrm{Zn}$, and Se concentrations in pasture samples were higher than the recommended level [17]. The study found that Fe was excessive in herbage which may cause absorption of $\mathrm{P}$, $\mathrm{Mn}$, and $\mathrm{Cu}$ of the sheep [21]. Weak acid and neutral environmental soils are beneficial to the absorption of elemental Fe by plants [8], which may be responsible for excessive Fe content in herbage.

The abnormal content of mineral elements in animals, especially in the blood, kidney, liver and other parts, can indicate the animal has a disease or is in a poisoning state [26]. Zn and $\mathrm{Cu}$ are the most important essential trace minerals playing a significant role in the growth and development of animal [27]. Underwood [4] showed that serum $\mathrm{Cu}, \mathrm{Zn}, \mathrm{Fe}$, and Se contents of serum for sheep should be from 0.19 to $0.58 \mathrm{mg} / \mathrm{L}$, 0.4 to $0.6 \mathrm{mg} / \mathrm{L}, 0.19$ to $2.21 \mathrm{mg} / \mathrm{L}$, and 0.02 to $0.04 \mathrm{mg} / \mathrm{L}$, respectively. In the ruminants, average blood $\mathrm{Cu}$ values of $<0.5$ $\mu \mathrm{g} / \mathrm{mL}$ are a sign of severe $\mathrm{Cu}$ deficiency [28]. The mean concentration of $\mathrm{Cu}$, observed in the present study was $0.27 \mathrm{mg} / \mathrm{L}$, which was remarkably lower than the recommended value. These levels of serum Fe and $\mathrm{Zn}$ were higher than the recommended value. The results suggested that it is likely most of the sheep were deficient in $\mathrm{Cu}$, however, serum Mn concentrations were in normal range. Besides, the content of elemental Se in the blood of sheep was close to the recommended value. NRC [29] pointed out that when the total Se content of the soil is less than $0.5 \mathrm{mg} / \mathrm{kg} \mathrm{DM}$, the lack of elemental Se can occur in livestock grazing in the area. The soil Se content in this study was found to be less than $0.5 \mathrm{mg} / \mathrm{kg} \mathrm{DM}$ (Table 1), which further explains the lack of Se in animals of the region.

Significant correlation coefficients under this study were found for soil and herbage accounting $\mathrm{Ca}, \mathrm{P}, \mathrm{Na}, \mathrm{Fe}, \mathrm{Mn}$, and $\mathrm{Zn}$. The mineral contents of the herbage depend upon the type of the soil and environmental conditions in which they grow $[24,25]$. Usually, the content of mineral elements in the soil can meet the needs of plant growth and development. However, the effectiveness of an element is often reduced by the influence of soil properties (particle size, $\mathrm{pH}$, water content, etc.), resulting in a decrease in the effective content of mineral elements in the soil [30]. As reported, there is a close relationship between soil minerals and herbage mineral contents, if the soil is low in essential minerals the uptake by roots will be impaired [31-33]. The correlation coefficients values between herbage and sheep were significantly different for all of the minerals except for P, Cu and Se. The correlation coefficient between herbage and sheep was significant for $\mathrm{K}(0.88)$, $\mathrm{Na}$ (0.75), $\mathrm{Ca}(0.74), \mathrm{Mg}$ (0.67), Fe (0.83), $\mathrm{Mn}$ (0.95), and $\mathrm{Zn}$ (0.92). However, such correlations were not found between the mineral levels in sheep and in soil except for $\mathrm{Na}(0.75)$, $\mathrm{Fe}$ (0.91), $\mathrm{Mn}$ (0.97), and $\mathrm{Zn}$ (0.94). The findings under this study are opposite to those reported by Wang [11], who reported that no correlations were found between soil, herbage, and blood of sheep in Huangcheng area of Qilian Mountains. Under this current study, regression of minerals in soils and herbage revealed positive linear relationships; however, the correlation values are too small except for $\mathrm{Ca}, \mathrm{P}, \mathrm{Na}, \mathrm{Fe}, \mathrm{Mn}$, and $\mathrm{Zn}$. The regression equation developed to predict the mineral concentration in sheep based on the soil and herbage mineral content showed positive relationship for $\mathrm{Ca}, \mathrm{K}, \mathrm{Mg}$, $\mathrm{Na}, \mathrm{Fe}, \mathrm{Zn}, \mathrm{Mn}$, and Se suggesting the possibility of prediction the mineral status in sheep.

When grazing, the mineral elements in soil and herbage will eventually be reflected in livestock [11]. The mineral elements in herbage has a crucial influence on the content and balance of mineral elements in livestock. The deficiencies of mineral elements in herbage will finally predispose to a deficient condition in serum concentrations of grazing livestock [34], and a limiting deficiency of $\mathrm{P}, \mathrm{Na}$, and $\mathrm{K}$ would occur under the current study but soil ingestion assuaged some of the $\mathrm{K}$ and $\mathrm{Na}$ deficiency. In addition, livestock of different species and physiological periods may require different levels of minerals. For instances, grazing cows require higher $\mathrm{Mg}$ levels during lactation [35]. Growing young animals and productive animals would require higher mineral levels than other physiological stages [36]. Although the results obtained under this trial were from castrated sheep, the findings could be further implemented to other livestock together with long term feeding trials to offer more information on other species of livestock. 
The experiment carried out in the high land of Qilian Mountain, northwestern of China, assessing the mineral contents in soil, herbage and sheep serum, resulted in useful information on the mineral status and the soil-herbage-sheep relationship. The results revealed that there were variations of both macro and micro minerals among districts. Among others, $\mathrm{Na}$ and $P$ deficiency could be a prevalent deficiency in sheep. Hence, salt-block containing these minerals should be supplemented to ensure better productivity of sheep grazing in the highlands of China.

\section{CONFLICT OF INTEREST}

We certify that there is no conflict of interest with any financial organization regarding the material discussed in the manuscript.

\section{ACKNOWLEDGMENTS}

We gratefully thank Zhouwen Ma and Shulin Wang for their assistance. We also express our great appreciation to the anonymous reviewers and the editor for their valuable comments and support in the revision. This study was supported by the Second Tibetan Plateau Scientific Expedition (STEP) program (XDA20060700), Program for Changiiang Scholars and Innovative Research Team in University (IRT_17R50), Major Special Science and Technology Project of Gansu Province (18ZD2FA009), Strategic Priority Research Program of Chinese Academy of Sciences, Grant No. XDA20100102, National Natural Science Foundation of China (No. 31672472).

\section{REFERENCES}

1. Zhao Y, Wu F, Fang X, Yang Y. Topsoil C/N ratios in the Qilian Mountains area: implications for the use of subaqueous sediment $\mathrm{C} / \mathrm{N}$ ratios in paleo-environmental reconstructions to indicate organic sources. Palaeogeogr Palaeoclimatol Palaeoecol 2015;426:1-9. https://doi.org/10.1016/j.palaeo.2015.02.038

2. Li B, Sun Y, Guo W, et al. The mechanism and verification analysis of permafrost-associated gas hydrate formation in the qilian mountain, northwest china. Mar Petrol Geol 2017; 86:787-97. https://doi.org/10.1016/j.marpetgeo.2017.05.036

3. Mcdowell LR. Feeding minerals to cattle on pasture. Anim Feed Sci Technol 1996;60:247-71. https://doi.org/10.1016/ 0377-8401(96)00983-2

4. Underwood EJ, Suttle NF. The mineral nutrition of livestock. London, UK: CABI Publishing; 1999.

5. Judson GJ, Mcfarlane JD. Mineral disorders in grazing livestock and the usefulness of soil and plant analysis in the assessment of these disorders. Aust J Exp Agric 1998;38:707-23. https://doi.org/10.1071/EA97145

6. Khan ZI, Hussain A, Ashraf M, Ashraf MY, Mcdowell LR.
Macromineral status of grazing sheep in a semi-arid region of Pakistan. Small Rumin Res 2007;68:279-84. https://doi.org/ 10.1016/j.smallrumres.2005.11.003

7. Soder KJ, Stout WL. Effect of soil type and fertilization level on mineral concentration of pasture: potential relationships to ruminant performance and health. J Anim Sci 2003;81: 1603-10. https://doi.org/10.2527/2003.8161603x

8. Kumaresan A, Bujarbaruah KM, Pathak KA, Brajendra, Ramesh T. Soil-plant-animal continuum in relation to macro and micro mineral status of dairy cattle in subtropical hill agro ecosystem. Trop Anim Health Prod 2010;42:569-77. https://doi.org/10. 1007/s11250-009-9459-8

9. Jurjanz S, Collas C, Lastel ML, et al. Evaluation of soil intake by growing creole young bulls in common grazing systems in humid tropical conditions. Animal 2017;11:1363-71. https:// doi.org/10.1017/S1751731116002755

10. Rodrigues SM, Pereira E, Duarte AC, Römkens PFAM. Derivation of soil to plant transfer functions for metals and metalloids: impact of contaminant's availability. Plant Soil 2012; 361:329-41. https://doi.org/10.1007/s11104-012-1249-9

11. Wang H, Liu YM, Qi ZM, et al. The estimation of soil trace elements distribution and soil-plant-animal continuum in relation to trace elements status of sheep in huangcheng area of qilian mountain grassland, China. J Integr Agric 2014;13: 140-7. https://doi.org/10.1016/S2095-3119(13)60504-3

12. Sharma MC, Joshi C, Gupta S. Prevalence of mineral deficiency in soil, plants and cattle of certain districts of Uttar Pradesh. Indian J Vet Med 2003;23:4-8.

13. Xin GS, Hu Z, Zhou W, Yang ZQ, Guo XS, Long RJ. Determination of inorganic elements in the soil-grass-animal system by sealed microwave digestion ICP-AES. Spectrosc Spect Anal 2010;30:546-50. https://doi.org/10.3964/j.issn.1000-0593(2010) 02-0546-05

14. Whetter PA, Ullrey DE. Improved fluorometric method for determining selenium. J Assoc Off Anal Chem 1978;61:927930.

15. Rhue RD, Kidder G. Analytical procedures used by the IFAS extension soil laboratory and the interpretation of results. Gainesville, FL, USA: Soil Science Department, University of Florida; 1983.

16. Viets FG, Lindsay WL. Testing soils for zinc, copper, manganese and iron. In: Walsh LM, Beaton J, editors. Soil testing and plant analysis. Madison WI, USA: Soil Science Society of America; 1973. p. 153-72.

17. Freer M, Dove H, Nolan JV. Nutrient requirements of domesticated ruminants. Collingwood Australia: CSIRO Publishing; 2007.

18. Xin GS, Long RJ, Guo XS, et al. Blood mineral status of grazing Tibetan sheep in the northeast of the Qinghai-Tibetan Plateau. Livest Sci 2011;136:102-7. https://doi.org/10.1016/j.livsci.2010. 08.007

19. Masters DG, Purser DB, Yu SX, et al. Mineral nutrition of 
grazing sheep in northern china. I. Macro-minerals in pasture, feed supplements and sheep. Asian-Australas J Anim 1993;6: 99-105. https://doi.org/10.5713/ajas.1993.99

20. Long RJ, Zhang DG, Wang X, Hu ZZ, Dong SK. Effect of strategic feed supplementation on productive and reproductive performance in yak cows. Prev Vet Med 1999;38:195-206. https://doi.org/10.1016/S0167-5877(98)00125-1

21. McDowell LR. Minerals in animal and human nutrition, second ed. Amsterdam, The Netherland: Elsevier Science; 2003.

22. Ashraf MY, Khan A, Ashraf, Zafar S. Studies on the transfer of mineral nutrients from feed, water, soil and plants to buffaloes under arid environments. J Arid Environ 2006;65:632-43. https://doi.org/10.1016/j.jaridenv.2005.10.003

23. Adams F, Hartzog DL. The nature of yield responses of Florunner peanuts to lime. Peanut Sci 1980;7:120-3. https:/doi.org/ 10.3146/i0095-3679-7-2-15

24. Khan M, Hussain F, Khan FU, Musharaf S, Imdadullah. Elemental analysis of ten plant species at three phenological stages. Pak J Pharm Sci 2017;30:459-66.

25. Vondráčková S, Hejcman M, Száková J, Müllerová V, Tlustoš P. Soil chemical properties affect the concentration of elements $(\mathrm{N}, \mathrm{P}, \mathrm{K}, \mathrm{Ca}, \mathrm{Mg}, \mathrm{As}, \mathrm{Cd}, \mathrm{Cr}, \mathrm{Cu}, \mathrm{Fe}, \mathrm{Mn}, \mathrm{Ni}, \mathrm{Pb}$, and $\mathrm{Zn}$ ) and their distribution between organs of Rumex obtusifolius. Plant Soil 2014;379:231-45. https://doi.org/10.1007/s11104-0142058-0

26. Sedat Çetin, Fatmagül Yur. Levels of trace elements in muscle and kidney tissues of sheep with fluorosis. Biol Trace Elem Res 2016;174:82-84. https://doi.org/10.1007/s12011-016-0694-3

27. Yildiz A, Balikci E. Association between some mineral and embryonic mortality in the sera of cows. J Fac Vet Med 2004; 15:11-5.

28. Zhou L, Long R, Pu X, Qi J, Zhang W. Studies of a naturally occurring sulfur-induced copper deficiency in przewalski's gazelles. Can Vet J 2009;50:1269-72.

29. NRC. Nutrition requirements of sheep, 6th ed. Washington, DC, USA: National Academy of Science; 1985.

30. Tessema ZK, de Boer WF, Baars RMT, Prins HHT. Changes in soil nutrients, vegetation structure and herbaceous biomass in response to grazing in a semi-arid savanna of Ethiopia. J Arid Environ 2011;75:662-70. https://doi.org/10.1016/j.jaridenv. 2011.02.004

31. Grzegorczyk S, Olszewska M, Alberski J. Accumulation of copper, zinc, manganese and iron by selected species of grassland legumes and herbs. J Elem 2014;19:109-18. https://doi. org/10.5601/jelem.2014.19.1.583

32. Oliveira RS, Galvão HC, de Campos MCR, Eller CB, Pearse SJ, Lambers H. Mineral nutrition of campos rupestres plant species on contrasting nutrient-impoverished soil types. New Phytol 2015;205:1183-94. https://doi.org/10.1111/nph.13175

33. Desjardins D, Brereton NJB, Marchand L, Brisson J, Pitre FE, Labrecque M. Complementarity of three distinctive phytoremediation crops for multiple-trace element contaminated soil. Sci Total Environ 2018;610-1:1428-38. https://doi.org/ 10.1016/j.scitotenv.2017.08.196

34. Cabrera MC, Saadoun A. An overview of the nutritional value of beef and lamb meat from South America. Meat Sci 2014; 98:435-44. https://doi.org/10.1016/j.meatsci.2014.06.033

35. Schonewille JT. Magnesium in dairy cow nutrition: an overview. Plant Soil 2013;368:167-78. https://doi.org/10.1007/ s11104-013-1665-5

36. Dove H, Masters DG, Thompson AN. New perspectives on the mineral nutrition of livestock grazing cereal and canola crops. Anim Prod Sci 2016;56:1350-60. https://doi.org/10. 1071/AN15264 